\title{
Effect of rising body temperature on respiratory chemosensitivity to $\mathrm{CO}_{2}$
}

\author{
Keiji Hayashi ${ }^{*}$, Takeshi Ogawa ${ }^{2}$, Koji Sugiyama ${ }^{3}$ \\ From 15th International Conference on Environmental Ergonomics (ICEE XV) \\ Portsmouth, UK. 28 June - 3 July 2015
}

\section{Introduction}

A rise in body temperature $\left(\mathrm{T}_{\mathrm{b}}\right)$ is known to cause minute ventilation $\left(\mathrm{V}_{\mathrm{E}}\right)$ to increase. However, the mechanism of the ventilatory response to rising $\mathrm{T}_{\mathrm{b}}$ is still unclear. In the context of the relationship between $V_{E}$ and $T_{b}$, it is known that respiratory chemosensitivity is influenced by $\mathrm{T}_{\mathrm{b}}$, and that a rise in $\mathrm{T}_{\mathrm{b}}$ of more than $0.7^{\circ} \mathrm{C}$ enhances respiratory chemosensitivity [1]. It is not known, however, whether increases in $T_{b}$ less than $0.7{ }^{\circ} \mathrm{C}$ also influence respiratory chemosensitivity. The aim of this study was to clarify the effect of mild hyperthermia $\left(0.3{ }^{\circ} \mathrm{C}\right.$ and $\left.0.7{ }^{\circ} \mathrm{C}\right)$ on respiratory chemosensitivity.

\section{Methods}

Eight persons (five males and three females, mean (SD) age 25 (10) years, height $171.5(8.9) \mathrm{cm}$, weight 66.9 $(8.7) \mathrm{kg}$ ) participated in the study. All were lowlanders and had not been exposed to altitude above $1,000 \mathrm{~m}$ within the 6 months prior the study. We measured sublingual temperature $\left(\mathrm{T}_{\mathrm{sl}}\right)$ as an index of $\mathrm{T}_{\mathrm{b}}$, and measured respiratory chemosensitivity to $\mathrm{CO}_{2}$ using a rebreathing method [2]. The subjects wore a mask connected to a closed one-way circuit with a rubber bag containing the test gas $\left(7 \% \mathrm{CO}_{2}, 43 \% \mathrm{O}_{2}, 50 \% \mathrm{~N}_{2}\right)$. Rebreathing was terminated when the inspired $\mathrm{CO}_{2}$ fraction reached $9.2 \%$. This test was performed before heating $\left(\Delta \mathrm{T}_{\mathrm{sl}}=0{ }^{\circ} \mathrm{C}\right)$ and during heating $\left(\Delta \mathrm{T}_{\mathrm{sl}}=0.3{ }^{\circ} \mathrm{C}\right.$ and $\left.0.7^{\circ} \mathrm{C}\right)$. Measurements were made twice with a 15 -min interval between tests at $\Delta \mathrm{T}_{\mathrm{sl}}=0^{\circ} \mathrm{C}, 0.3^{\circ} \mathrm{C}$ and $0.7^{\circ} \mathrm{C}$. During the experiment subjects wore a waterperfused suit. The initial water temperature was $35^{\circ} \mathrm{C}$ and was increased to $45^{\circ} \mathrm{C}$.

* Correspondence: khayashi@u-shizuoka-ken.ac.jp

${ }^{1}$ Junior College, University of Shizuoka, Shizuoka, Japan

Full list of author information is available at the end of the article

\section{Results}

Before heating mean (SD) $\mathrm{T}_{\mathrm{sl}}$ was $36.15(0.22){ }^{\circ} \mathrm{C}\left(\Delta \mathrm{T}_{\mathrm{sl}}=\right.$ $\left.0{ }^{\circ} \mathrm{C}\right)$ and rose to $36.47(0.21){ }^{\circ} \mathrm{C}$ at $\Delta \mathrm{T}_{\mathrm{sl}}=0.3{ }^{\circ} \mathrm{C}$ and then to $36.87(0.21)^{\circ} \mathrm{C}$ at $\Delta \mathrm{T}_{\mathrm{sl}}=0.7{ }^{\circ} \mathrm{C}$ during heating. While subjects breathed the $\mathrm{CO}_{2}$-rich mixture, $\mathrm{V}_{\mathrm{E}}$ was 1.49 (0.68) L. $\mathrm{min}^{-1} \cdot \mathrm{mmHg}^{-1}\left(\Delta \mathrm{T}_{\mathrm{sl}}=0{ }^{\circ} \mathrm{C}\right), 1.52$ (0.75) L. $\mathrm{min}^{-1} \cdot \mathrm{mmHg}^{-1}\left(\Delta \mathrm{T}_{\mathrm{s} 1}=0.3^{\circ} \mathrm{C}\right)$ and $1.75 \pm$ $0.98 \mathrm{~L} \cdot \mathrm{min}^{-1} \cdot \mathrm{mmHg}^{-1}\left(\Delta \mathrm{T}_{\mathrm{sl}}=0.7^{\circ} \mathrm{C}\right)$. The tidal volume was $44.7(12.4) \mathrm{mL} \cdot \mathrm{mmHg}^{-1}\left(\Delta \mathrm{T}_{\mathrm{sl}}=0^{\circ} \mathrm{C}\right)$, $55.4(24.9)$ $\mathrm{mL} \cdot \mathrm{mmHg}^{-1}\left(\Delta \mathrm{T}_{\mathrm{sl}}=0.3^{\circ} \mathrm{C}\right)$ and 61.9 (19.5) $\mathrm{mL} \cdot \mathrm{mmHg}^{-1}$ $\left(\Delta \mathrm{T}_{\mathrm{sl}}=0.7^{\circ} \mathrm{C}\right)(\mathrm{P}<0.06)$. The respiratory frequency was $0.47(0.38)$ breaths. $\mathrm{min}^{-1} \cdot \mathrm{mmHg}^{-1}\left(\Delta \mathrm{T}_{\mathrm{sl}}=0{ }^{\circ} \mathrm{C}\right)$, $0.40(0.42)$ breaths. $\mathrm{min}^{-1} \cdot \mathrm{mmHg}^{-1}\left(\Delta \mathrm{T}_{\mathrm{sl}}=0.3^{\circ} \mathrm{C}\right)$ and 0.37 (0.41) breaths. $\mathrm{min}^{-1} \cdot \mathrm{mmHg}^{-1}\left(\Delta \mathrm{T}_{\mathrm{sl}}=0.7^{\circ} \mathrm{C}\right)$.

\section{Discussion}

These results suggest that increases in $\mathrm{T}_{\mathrm{sl}}$ less than $0.7^{\circ} \mathrm{C}$ do not influence respiratory chemosensitivity to $\mathrm{CO}_{2}$, though the respiratory pattern did tend to change. The ventilatory response to rising $\mathrm{T}_{\mathrm{b}}$ has a threshold around $38^{\circ} \mathrm{C}$ (esophageal temperature) in the resting state [3]. Moreover, we suggest that increasing the inspired $\mathrm{CO}_{2}$ fraction did not reduce that threshold to the temperatures reached in the present study $\left(\mathrm{T}_{\mathrm{sl}}\right.$ around $\left.37^{\circ} \mathrm{C}\right)$.

\section{Conclusion}

Our findings suggest that respiratory chemosensitivity is not affected by mild hyperthermia $\left(\sim 0.7^{\circ} \mathrm{C}\right.$ rise in body temperature). It is possible that there is a $\mathrm{T}_{\mathrm{b}}$ threshold for changes in respiratory chemosensitivity that is greater than around $37^{\circ} \mathrm{C}$.

\footnotetext{
Authors' details

'Junior College, University of Shizuoka, Shizuoka, Japan. ${ }^{2}$ Osaka Kyoiku University, Osaka, Japan. ${ }^{3}$ Faculty of Education, Shizuoka University, Shizuoka, Japan.

Published: 14 September 2015
} 


\section{References}

1. Natalino MR, Zwillich CW, Weil JV: Effects of hyperthermia on hypoxic ventilatory response in normal man. J Lab Clin Med 1977, 89:564-572.

2. Read DJA: Clinical method for assessing the ventilatory response to carbon dioxide. Australas Ann Med 1967, 16:20-32.

3. Fujii N, Honda Y, Hayashi K, Soya H, Kondo N, Nishiyasu T: Comparison of hyperthermic hyperpnea elicited during rest and submaximal, moderate-intensity exercise. J Appl Physiol 2008, 104:998-1005.

doi:10.1186/2046-7648-4-S1-A152

Cite this article as: Hayashi et al:: Effect of rising body temperature on respiratory chemosensitivity to $\mathrm{CO}_{2}$. Extreme Physiology \& Medicine 2015 4(Suppl 1):A152.

Submit your next manuscript to BioMed Central and take full advantage of:

- Convenient online submission

- Thorough peer review

- No space constraints or color figure charges

- Immediate publication on acceptance

- Inclusion in PubMed, CAS, Scopus and Google Scholar

- Research which is freely available for redistribution

Submit your manuscript at www.biomedcentral.com/submit
C Biomed Central 